\title{
Public Transit Riders' Perceptions and Experience of Safety: COVID-19 Lessons from Edmonton
}

\author{
Bogdan Kapatsila', Emily Grise \\ ${ }^{1}$ School of Urban and Regional Planning, University of Alberta \\ Keywords: public transit marketing, customer experience, covid-19, transit safety, public transit \\ 10.32866/001c.19046
}

Findings

This study aims to understand who and under what circumstances is more likely to travel and feel safe using public transit in Edmonton, Canada, amidst the COVID-19 pandemic, by analyzing data from an online survey conducted during the summer of 2020. We provide empirical evidence that an individual better informed about the measures Edmonton Transit Service is taking to ensure physical distancing and meet the health and safety concerns of riders is more likely to feel safe using public transit. It is recommended that transit agencies continuously communicate with riders regarding ongoing efforts to promote the health and safety of all users.

\section{QUESTIONS}

Public transit ridership has plummeted in Edmonton, Canada, and even with the restoration of pre-COVID-19 level of service and start of K-12 and postsecondary schools, it has not exceeded half of what it was before the pandemic (Romero 2020). Similar trends could be observed in other North American cities (Transit 2020a), and in the first months of the pandemic, several surveys sought to answer who were the people who continued riding public transit. In US cities, these predominantly comprised women, people of color, lowpaid workers, and those without access to a car (Transit 2020b). Canadian researchers conducted surveys in Toronto and Vancouver and reported that the riders who did not stop using public transit were more likely to be male, persons with a disability, people of color, and older than 50 years of age (Palm et al. 2020a, 2020b). Based on these reports, we hypothesized that a profile of a public transit rider during the COVID-19 pandemic in Edmonton will have similar socioeconomic characteristics.

At the same time, the pandemic has also introduced new requirements to the customer experience that public transit riders expect to receive. Even in the pre-COVID-19 world, transit vehicle occupancy and safety strongly influenced user satisfaction and customer loyalty (van Lierop and El-Geneidy 2016). Meanwhile, the pandemic put a focus on cleaning and sanitation practices and clear communication of the efficacy of measures that agencies take to ensure the health and safety of their patrons (de Cotret et al. 2020). We use that knowledge to hypothesize that riders place a high value on these efforts to feel safe using public transit in Edmonton during the COVID-19 pandemic. 


\section{METHODS}

Data for this study came from an online survey with the members of the Edmonton Insight Community conducted between June 25th and July 8th, 2020. Given that it was a convenience sample survey, we compared it to the 2016 Canadian census for the City of Edmonton (Statistics Canada 2017) and found differences between all key demographics. This comparison and descriptive statistics for all variables are presented in Table 1. We used four logistic regression models in $\mathrm{R}$ statistical program to assess the respondent's likelihood to travel for any purpose in the next three months (model 1) and whether they will feel safe using public transit in the next three months (models 2,3 , and 4). We controlled for respondents' perceptions of safety in models 2 and 4, experience of using public transit in models 3 and 4, and demographic variables in all four models. In model 1 the dependent variable reflects respondents' answer to the question 'Thinking of the next three months, do you think you will need to travel?', while for models 2 , 3, and 4 the dependent variable was based on the question 'How safe or unsafe would you feel using public transit (including Disabled Adult Transit Service (DATS)) in Edmonton in the next three months?'. The latter question was asked using a Likert scale, and we converted this variable into a binary variable by recoding 'very safe' and 'somewhat safe' answers as 'yes', while 'somewhat unsafe' and 'very unsafe' as ' $n o$ '. Similarly, we recoded perceptions and experience variables by combining 'strongly disagree' and 'somewhat disagree' answers as 'disagree', and 'somewhat agree' with 'strongly agree' into an answer of 'agree'. Models 1 and 2 included both riders who continued riding transit during the pandemic and transit users who have not used transit since the pandemic, while models 3 and 4 used data of current riders only.

All models were checked for multicollinearity using Variance Inflation Factor (VIF), and variables that had a VIF larger than 5 were removed from the models. We also explored interaction effects among income, gender, age, education, type of employment, and car ownership variables in the modeling process, which didn't result in any significant discoveries. Finally, the descriptive power of each model was evaluated using McFadden's pseudo- $\mathrm{R}^{2}$ statistic and given that it was more than 0.2 for model 1 and increased for each subsequent model, we can state that they succeeded to explain the variation in the data. In addition, we used Akaike information criterion (AIC) to compare the fitness of model 3 and model 4 , it suggested that model 4 fitted the data better than model 3 . 


\begin{tabular}{|c|c|c|c|c|c|}
\hline & $\begin{array}{l}\text { Model 1: Need to travel in } \\
\text { next } 3 \text { months }\end{array}$ & $\begin{array}{l}\text { Model 2: Feel safe } \\
\text { using PT (1) }\end{array}$ & $\begin{array}{l}\text { Model 3: Feel safe } \\
\text { using PT (2) }\end{array}$ & $\begin{array}{l}\text { Model 4: Feel safe } \\
\text { using PT (3) }\end{array}$ & $\begin{array}{c}\text { Edmonton } \\
\text { (2016 Census) }\end{array}$ \\
\hline Population & 1,182 & 1,133 & 236 & 214 & 932,546 \\
\hline \multicolumn{6}{|c|}{ Need to travel in next 3 months } \\
\hline Yes & $51 \%$ & NA & NA & NA & NA \\
\hline No & $49 \%$ & & & & \\
\hline \multicolumn{6}{|c|}{ Feel safe using PT in next 3 months } \\
\hline Yes & NA & $27 \%$ & $48 \%$ & $50 \%$ & NA \\
\hline No & & $73 \%$ & $52 \%$ & $50 \%$ & \\
\hline \multicolumn{6}{|c|}{ Demographics } \\
\hline \multicolumn{6}{|l|}{ Age } \\
\hline 18-34 years old & $23 \%$ & $23 \%$ & $23 \%$ & $22 \%$ & $N A^{1}$ \\
\hline $35-54$ years old & $54 \%$ & $54 \%$ & $54 \%$ & $56 \%$ & $27.4 \%$ \\
\hline $55-74$ years old & $23 \%$ & $23 \%$ & $23 \%$ & $22 \%$ & $18.3 \%$ \\
\hline Under $\$ 30,000$ & $2 \%$ & $2 \%$ & $9 \%$ & $8 \%$ & $12.8 \%$ \\
\hline$\$ 30,000$ to $\$ 59,999$ & $11 \%$ & $11 \%$ & $19 \%$ & $19 \%$ & $19.5 \%$ \\
\hline$\$ 60,000$ to $\$ 99,999$ & $27 \%$ & $27 \%$ & $34 \%$ & $34 \%$ & $25 \%$ \\
\hline Over $\$ 100,000$ & $60 \%$ & $60 \%$ & $38 \%$ & $39 \%$ & $42.7 \%$ \\
\hline \multicolumn{6}{|l|}{ Gender } \\
\hline Female & $52 \%$ & $51 \%$ & $53 \%$ & $52 \%$ & $50 \%$ \\
\hline Male & $47 \%$ & $48 \%$ & $44 \%$ & $46 \%$ & $50 \%$ \\
\hline Other & $1 \%$ & $1 \%$ & $3 \%$ & $2 \%$ & $N^{2}{ }^{2}$ \\
\hline \multicolumn{6}{|l|}{ Education } \\
\hline High School & $8 \%$ & $8 \%$ & $12 \%$ & $12 \%$ & $27.4 \%$ \\
\hline College/Prof. School & $28 \%$ & $27 \%$ & $31 \%$ & $32 \%$ & $32.7 \%$ \\
\hline Undergraduate & $40 \%$ & $40 \%$ & $36 \%$ & $35 \%$ & $18.5 \%$ \\
\hline Post-graduate & $24 \%$ & $25 \%$ & $21 \%$ & $21 \%$ & $6.5 \%$ \\
\hline \multicolumn{6}{|l|}{ Employment } \\
\hline \multicolumn{6}{|l|}{ Industry } \\
\hline All other industries & $34 \%$ & $33 \%$ & $41 \%$ & NA & $73.8 \%$ \\
\hline Health, Social Care & $13 \%$ & $12 \%$ & $17 \%$ & & $12.1 \%$ \\
\hline Professional, Science & $22 \%$ & $23 \%$ & $13 \%$ & & $7.2 \%$ \\
\hline Government & $31 \%$ & $32 \%$ & $29 \%$ & & $6.9 \%$ \\
\hline
\end{tabular}




\begin{tabular}{|c|c|c|c|c|c|}
\hline & $\begin{array}{l}\text { Model 1: Need to travel in } \\
\text { next } 3 \text { months }\end{array}$ & $\begin{array}{l}\text { Model 2: Feel safe } \\
\text { using PT (1) }\end{array}$ & $\begin{array}{l}\text { Model 3: Feel safe } \\
\text { using PT (2) }\end{array}$ & $\begin{array}{l}\text { Model 4: Feel safe } \\
\text { using PT (3) }\end{array}$ & $\begin{array}{l}\text { Edmonton } \\
\text { (2016 Census) }\end{array}$ \\
\hline \multicolumn{6}{|l|}{ Access to car } \\
\hline Yes & $89 \%$ & $89 \%$ & $62 \%$ & $64 \%$ & $N A^{3}$ \\
\hline No & $11 \%$ & $11 \%$ & $38 \%$ & $36 \%$ & \\
\hline \multicolumn{6}{|c|}{ Transit use in the past } \\
\hline \multicolumn{6}{|c|}{ How often did you use transit before March 2020? } \\
\hline Often (multiple times per week) & $44 \%$ & $45 \%$ & NA & NA & NA \\
\hline Sometimes (a few times a month) & $16 \%$ & $16 \%$ & & & \\
\hline Rarely (one/two times a month) & $40 \%$ & $39 \%$ & & & \\
\hline \multicolumn{6}{|c|}{ Have you used public transit within the last three months? } \\
\hline Yes & $23 \%$ & $21 \%$ & NA & NA & NA \\
\hline No & $77 \%$ & $79 \%$ & & & \\
\hline \multicolumn{6}{|c|}{ Perceptions } \\
\hline \multicolumn{6}{|c|}{ I feel that I can physical distance myself while riding on the bus } \\
\hline Disagree & NA & $61 \%$ & NA & $30 \%$ & NA \\
\hline Neither agree, nor disagree & & $15 \%$ & & $21 \%$ & \\
\hline Agree & & $24 \%$ & & $49 \%$ & \\
\hline \multicolumn{6}{|c|}{ I would only take transit if there are rules around limited occupancy } \\
\hline Disagree & NA & $20 \%$ & NA & $29 \%$ & NA \\
\hline Neither agree, nor disagree & & $21 \%$ & & $28 \%$ & \\
\hline Agree & & $59 \%$ & & $43 \%$ & \\
\hline \multicolumn{6}{|c|}{ I am worried about coming in contact with people who take transit } \\
\hline Disagree & NA & $19 \%$ & NA & $28 \%$ & NA \\
\hline Neither agree, nor disagree & & $16 \%$ & & $24 \%$ & \\
\hline Agree & & $65 \%$ & & $48 \%$ & \\
\hline \multicolumn{6}{|c|}{ I am comfortable using paper tickets and transfers } \\
\hline Disagree & NA & $24 \%$ & NA & $18 \%$ & NA \\
\hline Neither agree, nor disagree & & $16 \%$ & & $15 \%$ & \\
\hline Agree & & $60 \%$ & & $67 \%$ & \\
\hline \multicolumn{6}{|c|}{$\begin{array}{l}\text { I am confident that ETS can maintain the scheduled service frequency while } \\
\text { maintaining public health measures }\end{array}$} \\
\hline Disagree & NA & $42 \%$ & NA & $36 \%$ & NA \\
\hline Neither agree, nor disagree & & $21 \%$ & & $22 \%$ & \\
\hline Agree & & $37 \%$ & & $42 \%$ & \\
\hline \multicolumn{6}{|c|}{ Experience } \\
\hline \multicolumn{6}{|c|}{ I was aware of the measures ETS was taking to ensure physical distancing } \\
\hline Disagree & NA & NA & $11 \%$ & $10 \%$ & NA \\
\hline Neither agree, nor disagree & & & $6 \%$ & $5 \%$ & \\
\hline
\end{tabular}




\begin{tabular}{|c|c|c|c|c|c|}
\hline & $\begin{array}{l}\text { Model 1: Need to travel in } \\
\text { next } 3 \text { months }\end{array}$ & $\begin{array}{l}\text { Model 2: Feel safe } \\
\text { using PT (1) }\end{array}$ & $\begin{array}{l}\text { Model 3: Feel safe } \\
\text { using PT (2) }\end{array}$ & $\begin{array}{l}\text { Model 4: Feel safe } \\
\text { using PT (3) }\end{array}$ & $\begin{array}{l}\text { Edmonton } \\
\text { (2016 Census) }\end{array}$ \\
\hline Agree & & & $84 \%$ & $85 \%$ & \\
\hline \multicolumn{6}{|c|}{ On the bus, the seating restrictions allowed for physical distancing } \\
\hline Disagree & NA & NA & $24 \%$ & $22 \%$ & NA \\
\hline Neither agree, nor disagree & & & $16 \%$ & $16 \%$ & \\
\hline Agree & & & $60 \%$ & $62 \%$ & \\
\hline \multicolumn{6}{|c|}{ I was able to practice physical distancing } \\
\hline Disagree & NA & NA & $22 \%$ & $19 \%$ & NA \\
\hline Neither agree, nor disagree & & & $10 \%$ & $12 \%$ & \\
\hline Agree & & & $68 \%$ & $69 \%$ & \\
\hline \multicolumn{6}{|c|}{ Most of the other riders were following physical distancing rules } \\
\hline Disagree & NA & NA & $36 \%$ & $34 \%$ & NA \\
\hline Neither agree, nor disagree & & & $9 \%$ & $9 \%$ & \\
\hline Agree & & & $55 \%$ & $57 \%$ & \\
\hline
\end{tabular}

${ }^{1}$ Cannot make a direct comparison to the 2016 Canadian Census as age is grouped between 15 and 19 years.

${ }^{2}$ The 2016 Canadian Census did not give Canadians the option of responding to the sex question in a non-binary fashion.

${ }^{3}$ While the 2016 Canadian Census does not ask Canadians about vehicle ownership, the 2015 National Travel Survey observed 0.78 vehicles per person in the City of Edmonton (R.A. Malatest \& Associates 2018). 


\section{FINDINGS}

Table 2 summarizes the main findings of the study, with coefficients indicating the presence of the effect on the model, and average marginal effects (ME) quantifying it. We discuss demographic variables only for model 1 and focus on experience and perception variables of the other models, though demographic variables are reported for all models in Table 2. Model 1 looked at a respondent's likelihood to need to travel in the next 3 months based on their demographic features and history of transit use. We can be $99 \%$ confident that a rider between $55-74$ years of age is $12 \%$ more likely to need to travel in the next three months, while a person without access to a car is $15 \%$ more likely to do so, holding all other variables constant. Similarly, we can be as confident that health and social care workers are $12 \%$ more likely to need to travel than other occupations in the next three months, while government employees are $7 \%$ more likely to have that need at a $95 \%$ confidence interval, all else equal.

Model 2 looked at an individual's perception of safety using public transit. As it shows, we can be $99 \%$ certain that a person who agrees that they can physical distance themselves while riding on the bus is $22 \%$ more likely to feel safe using public transit, while the recognition that ETS can maintain the scheduled service frequency while maintaining public health measures increases the likelihood of feeling safe for a rider by $11 \%$, all else equal. Alternatively, the more concerned a person is with the rules around limited occupancy and coming in contact with people who take transit, the lower their likelihood to feel safe using public transit is.

Models 3 and 4 included only riders who used transit within the last three months. Given that ETS deployed a number of measures to ensure the safety of its riders, like overt cleaning activities, physical distancing signage and limited seating policy, as well as mandatory mask use (City of Edmonton 2020), in model 3, we controlled for the current riders' experience and saw that a person informed about the measures ETS was taking to ensure physical distancing, or who was able to practice physical distancing, or saw that other riders were doing so - is more likely to feel safe riding public transit. This means that ETS should continue communicating and enforcing ongoing health and safety measures to retain its riders. Model 4 highlights that when controlling for the experience of riders who used transit within the last three months, we see no significant difference between the effect of perception variables for this group and the rest of the sample in model 2. The only distinction is that current users in model 4 who neither agree, nor disagree that ETS can maintain the scheduled service frequency while maintaining public health measures, are 15\% less likely to feel safe using transit in the next 3 months, ceteris paribus. These findings suggest that ETS does not have to develop different strategies that target current and potential riders but maintain the existing level of safety and cleaning practices and ensure that all Edmontonians are aware of them. 


\begin{tabular}{|c|c|c|c|c|c|c|c|c|}
\hline \multirow{2}{*}{ Sample size } & \multicolumn{2}{|c|}{$\begin{array}{c}\text { Model 1: Need to travel in } \\
\text { next } 3 \text { months }\end{array}$} & \multicolumn{2}{|c|}{$\begin{array}{l}\text { Model 2: Feel safe } \\
\text { using PT (1) }\end{array}$} & \multicolumn{2}{|c|}{$\begin{array}{c}\text { Model 3: Feel safe } \\
\text { using PT (2) }\end{array}$} & \multicolumn{2}{|c|}{$\begin{array}{l}\text { Model 4: Feel safe } \\
\text { using PT (3) }\end{array}$} \\
\hline & Coeff. & ME & Coeff. & ME & Coeff. & ME & Coeff. & ME \\
\hline McFadden's pseudo $\mathrm{R}^{2}$ & \multicolumn{2}{|c|}{0.21} & \multicolumn{2}{|c|}{0.36} & \multicolumn{2}{|c|}{0.26} & \multicolumn{2}{|c|}{0.42} \\
\hline AIC & \multicolumn{2}{|c|}{1348.7} & \multicolumn{2}{|c|}{915.24} & \multicolumn{2}{|c|}{301.59} & \multicolumn{2}{|c|}{237.01} \\
\hline \multicolumn{9}{|c|}{ Demographics } \\
\hline $35-54$ years & 0.08 & 0.01 & 0.32 & 0.04 & 0.23 & 0.04 & -0.39 & -0.05 \\
\hline 55-74 years & $0.66^{* * *}$ & 0.12 & $0.64^{* *}$ & 0.07 & -0.03 & 0 & -0.27 & -0.03 \\
\hline \multicolumn{9}{|l|}{ Income $($ Ref. $<\$ 30,000)$} \\
\hline$\$ 30,000$ to $\$ 59,999$ & -0.58 & -0.11 & -0.35 & -0.04 & 0.09 & 0.02 & -0.2 & 0 \\
\hline$\$ 60,000$ to $\$ 99,999$ & -0.97 & -0.18 & -0.45 & -0.05 & -0.52 & -0.09 & -0.10 & -0.01 \\
\hline Over $\$ 100,000$ & -0.99 & -0.19 & -0.23 & -0.03 & 0.22 & 0.04 & 1.07 & 0.13 \\
\hline \multicolumn{9}{|l|}{ Gender (Ref. Female) } \\
\hline Other & 0.12 & 0.02 & -0.12 & -0.01 & 0.74 & 0.13 & -0.03 & 0 \\
\hline \multicolumn{9}{|c|}{ Education (Ref. High School) } \\
\hline College/Prof. School & 0.19 & 0.04 & -0.53 & -0.06 & 0.07 & 0.01 & -0.15 & -0.02 \\
\hline Undergraduate & 0.06 & 0.01 & $-0.98^{* * *}$ & -0.12 & 0.39 & 0.07 & -0.03 & 0 \\
\hline Post-graduate & 0.21 & 0.04 & $-0.87^{* *}$ & -0.10 & -0.33 & -0.06 & -0.28 & -0.04 \\
\hline \multicolumn{9}{|c|}{ Employment (Ref. full-time) } \\
\hline Part-time & -0.1 & -0.02 & $0.56^{*}$ & 0.07 & -0.36 & -0.06 & 0.13 & 0.02 \\
\hline \multicolumn{9}{|c|}{ Industry (Ref. all other industries) } \\
\hline Food Services & -1.27 & -0.24 & -1.3 & -0.15 & 0 & 0 & NA & NA \\
\hline Health, Social Care & $0.66^{* * *}$ & 0.12 & 0.27 & 0.03 & 0.41 & 0.7 & & \\
\hline Prof., Science, Tech. & 0.28 & 0.05 & 0.16 & 0.02 & 0.83 & 0.14 & & \\
\hline Government & $0.38^{* *}$ & 0.07 & 0.38 & 0.05 & 0.39 & 0.07 & & \\
\hline \multicolumn{9}{|l|}{ Access to car (Ref. Yes) } \\
\hline No & $0.78^{* * *}$ & 0.15 & -0.34 & -0.04 & 0.01 & 0.02 & 0.4 & 0.05 \\
\hline Sometimes & -0.24 & -0.04 & -0.2 & -0.02 & NA & NA & NA & NA \\
\hline Rarely & $-1.4^{* * *}$ & -0.26 & $-0.4^{*}$ & -0.05 & & & & \\
\hline Have you used public tra & & & & & & & & \\
\hline Yes & $1.67^{* * *}$ & 0.31 & $0.54^{* *}$ & 0.06 & NA & NA & NA & NA \\
\hline & Perception & & & & & & & \\
\hline
\end{tabular}


On the whole, our four models were successful in supporting the initial hypotheses. Model 1 shows that persons between 55-74 years of age, or healthcare, or government workers, are more likely to travel in the next three months, while a transit user who is better informed about the measures ETS is taking to ensure physical distancing is more likely to feel safe using public transit. It is recommended that transit agencies continuously communicate with riders regarding ongoing efforts to promote the health and safety of all users. This finding echoes previous research regarding the importance of an agency displaying and communicating its cleaning and sanitation practices to encourage Canadians to take transit again (de Cotret et al. 2020). When users are continuously informed and reminded about cleaning and sanitation efforts, riders are more likely to trust that transit agencies are meeting their health and safety concerns. Safety in transit is an important determinant of overall satisfaction (and loyalty) (van Lierop and El-Geneidy 2016), and therefore satisfying rider's concerns for personal safety is an essential step towards attracting riders back to transit safely before too much modal partition has happened (D’Angelo 2020).

\section{ACKNOWLEDGEMENTS}

We would like to thank Edmonton Transit Service (ETS) and Matt Dow from ETS for providing us with the data used in this analysis and two anonymous reviewers whose input helped us to strengthen the paper. 


\section{REFERENCES}

City of Edmonton. 2020. “Transit COVID-19 Updates.” https://www.edmonton.ca/ets/reducedtransit-service.aspx.

D’Angelo, M. 2020. “Transit Is in Grave Danger of Falling into a Death Spiral.” Policy Options, September 22, 2020. https://policyoptions.irpp.org/magazines/september-2020/transit-is-in-gravedanger-of-falling-into-a-death-spirall.

de Cotret, Y.R., I. Davidson, M. Iacobacci, and S. Dixon. 2020. “Urban Mobility's Routes to Recovery." 2020. https://www2.deloitte.com/content/dam/Deloitte/ca/Documents/publicsector/ca-urban-mobilitys-routes-to-recovery-en-aoda.pdf.

Palm, M., J. Allen, M. Widener, Y. Zhang, S. Farber, and N. Howell. 2020a. "Preliminary Results from the Public Transit and COVID-19 Survey." https://drive.google.com/file/d/ 1xtbl9nNNcjQFB51-crAGOyC0vSLCHw3M/view.

- - . 2020b. "Public Transit and COVID-19 Survey: Results from the City of Vancouver." https://drive.google.com/file/d/1xrHpwTg1fEuwAlLqJd-5N_Ouy89HYN4p/view.

R.A. Malatest \& Associates. 2018. "2015 Edmonton and Region Household Travel Survey.” Summary Report. https://www.edmonton.ca/transportation/RoadsTraffic/ 2015_HTS_SummaryReport.pdf.

Romero, D. 2020. "More Edmontonians Using Transit with School Underway, but Ridership Still Low: ETS. CTVNewsEdmonton,” September 15, 2020. https://edmonton.ctvnews.ca/moreedmontonians-using-transit-with-school-underway-but-ridership-still-low-ets-1.5105705.

Statistics Canada. 2017. “Census Profile, 2016 Census.” https://www12.statcan.gc.ca/censusrecensement/2016/dp-pd/prof/details/

page.cfm?Lang $=\mathrm{E} \& \mathrm{Geo} 1=\mathrm{CSD} \& \operatorname{Code} 1=4811061 \& \mathrm{Geo} 2=\mathrm{CD} \& \mathrm{Code} 2=4811 \&$ Search Text $=$ edmonton $\&$ Search Type $=\mathrm{B}$

Transit. 2020a. “How Coronavirus Is Disrupting Public Transit.” https://transitapp.com/ coronavirus.

- - . 2020b. "Who's Left Riding Public Transit? A COVID Data Deep-Dive." Medium, April 27, 2020. https://medium.com/transit-app/whos-left-riding-public-transit-hint-it-s-not-whitepeople-d43695b3974a.

van Lierop, D., and A. El-Geneidy. 2016. "Enjoying Loyalty: The Relationship between Service Quality, Customer Satisfaction, and Behavioral Intentions in Public Transit." Research in Transportation Economics 59 (November): 50-59. https://doi.org/10.1016/j.retrec.2016.04.001. 